\title{
NEW ADDITIONS IN BORAGINACEAE IN BHANDARA DISTRICT (M.S.)
}

\author{
P. T. Humane \\ Dharampeth M. P. Deo Memorial Science College, Nagpur. \\ e-mail: aareenpapa_2004@rediffmail.com
}

\begin{abstract}
:
During the course of floristic exploration of the Bhandara district, 11 species belonging to 06 genera have been reported, out of which 04 species are new records for the district. The information regarding morphological \& reproductive characters, their distribution and key for easy identification have been provided.
\end{abstract}

Keywords : Floristics, Bhandara district, new records.

\section{INTRODUCTION:}

The Bhandara district of Maharashtra, the area of present study is situated in between eastern longitude of $799^{\circ} 10^{\prime}$ to $79^{\circ} 20^{\prime}$ and northern latitude of $20^{\circ} 00^{\prime}$ to $20^{\circ} 05^{\prime}$. It has an undulating topography with an altitude range from 150 to $600 \mathrm{~m}$ and geographical area 5425 sq. $\mathrm{km}$.

Boraginaceae, a small family widely distributed in temperate and tropical region, but more abundant in the Mediterranean region. Members of the said family are herbs, shrubs or trees, characterized by leaves with rough hairs, inflorescences sometimes coiled at their tips, and fruit a capsule or drupe (fleshy) of 1-4 seeded nutlets. This family displays a range of differences in habit, leaf, inflorescence, flowers and fruit morphology.

Taxonomic literature reveals absence of extensive and intensive work on plants of Bhandara district. The present work is an initial attempt to fill this lacuna.

\section{MATERIAL AND METHODS:}

To study the members of the said family extensive and intensive visits were arranged to various regions of the district in different seasons. The plants were observed in their natural habitat and the phenological data were collected and recorded in the field diary. The multiple specimens of plants in flowering and fruiting stage were collected, preserved and their herbarium sheets were prepared. The field notes were incorporated with the specimens on the herbarium sheets.

The digital photographs of some unique plants were taken with their unique characteristics that can help in identifying the plants in the natural habitat.
Attempts have been made to use recent names and the list that follows the genera and species are arranged alphabetically. Artificial keys are prepared for the genera and species for the specimens collected for this study.

All the specimens of the taxa have been deposited in the herbarium of Department of Botany, Dharampeth M. P. Deo Memorial Science College, Nagpur.

\section{TAXONOMIC TREATMENT :}

\section{BORAGINACEAE JusS.}

\section{Key to the genera of Bhandara district.}

1. Plants mostly trees or shrubs:

2. Styles two or once forked or one:

3. Styles two or once forked. EHRETIA

3. Style one or not forked.

2. Styles four or twice forked. RORULA ... CORDIA

1. Plants mostly herbs, rarely under-shrubs:

4. Plants strictly prostrate flowers usually solitary. ... COLDENIA

4. Plants erect or procumbent, flowers not as above:

5. Flowers more than $1 \mathrm{~cm}$ wide, calyx winged or auricled. $\quad . . \quad$ TRICHODESMA

5. Flowers less than $1 \mathrm{~cm}$ wide, calyx not winged or auricled. ... HELIOTROPIUM

\section{COLDENIA $L$.}

Coldenia procumbens L. Sp. PI. 125. 1753; C. B. Cl. in Hook. f. Fl. Brit. India 4: 144. 1883; Cooke, Fl. Pres. Bombay 2: 271. 1958 (Repr.); Kazmi in J. Arnold Arbor. 51: 148. 1970. Ugemuge, Fl. Nag. Dist. 243. 1986. 'TRIPANKHI'.

Prostrate herb; stem villous. Leaves obovateoblong, base cuneate and very oblique, margin 
coarsely serrate or cranate serrate, apex obtuse, villous on both side. Flowers solitary, sessile, white. Sepals 4, ovate, acute, pilose. Corolla tubular, lobes 4, white. Stamens 4, slightly exserted. Fruit dry, pyramidal, 4-lobed, separating into 1 - celled beaked pyrenes. Pyrenes muriculate, hairy.

Common in rocky places. Fls. \& Frs. Dec. - May. Sipewada lake side, 374.

\section{CORDIA L.}

Cordia dichotoma Forst. f. Prodr. 18. 1786; Sant. in Rec. Bot. Surv. Ind. 16: 163. 1967 (3rd. Rev. ed.); Kazmi in J. Arnold Arbor. 51: 141. 1970. C. obliqua Willd. Phytogr. 4. t. 4. 1794; C.B.C1. in Hook. f. Fl. Brit. India 4: 137. 1883, excl. var. C. myxa auct. plur. non. L. 1753; C. B. Cl. in Hook. f. op. cit. 136; Cooke, Fl. Pres. Bombay 2: 265. 1958 (Repr. ). 'LASORA', 'BHOKAR'.

Moderate sized tree; stem and branches more or less glabrous; bark grey. Leaves alternate, broadly ovate or elliptic oblong, base rounded, sub- cordate or shortly cuneate, entire, apex acute or obtuse, glabrous on both sides. Flowers in terminal and axillary pedunculate cymose panicles, polygamous. Sepals glabrous or nearly so. Corolla tubular, 5- lobed, lobes oblong, obtuse. Fruits ovoid drupes supported on persistent calyx, pinkish- cream, pulp sticky, edible. Seeds $2-4$, stony.

Common in deciduous forest, also cultivated on agricultural field bunds. Fls. \& Frs. Jan.- Jun. Ambadi/ Khambadi, 468.

\section{EHRETIA L.}

E. laevis Roxb. PI. Cor. 1: 42, t. 55. 1795 \& Fl. Ind. 2:341. 1824; C. B. Cl. in Hook. f. Fl. Brit. India 4:141. 1883; Cooke, Fl. Pres. Bombay 2: 269. 1958 (Repr.); Kazmi in J. Arnold Arbor. 51: 147. 1970. 'AJAN VRIKHA'.

Medium sized tree; young branches pubescent, bark greyish brown. Leaves petiolate, elliptic oblong, alternate, base much variable, subcordate, rounded, cuneate, truncate, oblique, margins entire, glabrous and shining above, paler beneath. Flowers in much branched axillary and terminal corymbose cymes composed of unilateral spikes or racemes. Sepals ovate, acute, pubescent. Corolla tubular, white, lobes spreading, obtuse. Stamens and styles exserted. Fruits drupe, globose, lobed, turn orange- red when ripe.

Common in deciduous forests. Fls. \& Frs. Mar.Jun. Koka, 604.

\section{HELIOTROPIUM L.}

1. Calyx completely enveloping the fruit.

$$
\text { ... H. supinum }
$$

1. Calyx not completely enveloping the fruit:

2. Leaves more than 2 in. long.

$$
\text { ... H. indicum }
$$

2. Leaves less than 2 in. long:

3. Plants procumbent, leaves silky hairy beneath. $\quad$... $\quad$ H. ovalifolium

3. Plants erect, leaves strigose Hairy beneath ... Heliotropium sp.?

H. indicum L. Sp. PI. 130. 1753; C. B. Cl. in Hook. f. Fl. Brit. India 4: 152. 1883; Cooke, Fl. Pres. Bombay 2: 273. 1958 (Repr.). 'BHURUNDI'.

Erect branched herb; stem and branches hispid hairy, all hairs arising from bulbous base. Leaves ovate to ovate- oblong, alternate or subopposite, base decurent with petiole, rounded, sub-cordate, unequal, margins subserrate, acute, bulbous based strigose hairy above, pillose beneath. Flowers in axillary, extra- axillary or terminal 2- ranked, simple or forked scorpioid cymes. Sepals enequal, linearlanceolate, acute, hairy. Corolla tubular infundibuliform, lobes orbicular oblong, bluish white. Stamens and styles included. Fruit dry, 2- lobed pyrenes. Seeds 2- angled, beaked.

Common along road side near villages, also in sandy soils. Fls. \& Frs. Oct.- Apr. Somalwada, 186.

H. ovalifolium Forssk. Fl. Aeg.-Arab. 38. 1775; C. B. Cl. in Hook, f. Fl. Brit. India 4: 150. 1883; Cooke, Fl. Pres. Bombay 2: 278. 1958 (Rerp.); Kazmi in J. Arnold Arbor. 51: 178. 1970.; Naik, Fl. Marathwada. 568.1998.

Erect or procumbent herb; stem white silky pubescent. Leaves alternate, elliptic- oblong, base narrow, acute, apex obtuse or mucronulate, appressed hairy above, white silky beneath. Flowers in extra- axillary or terminal, simple or forked scorpioid cymes. Sepals much unequal, ovate- oblong to linear- lanceolate, appressed hairy. Corolla tubular, white. Stamens and styles included. Fruit dry pyrenes, not beaked, silky hairy. Seeds angled, beaked, hairy on convex back.

Common in all places of the region. Fls. \& Frs. Aug.- June. Parsodi/ Kesalwada, 150.

H. supinum L. Sp. PI. 130. 1753; C. B. Cl. in Hook. f. Fl. Brit. India 4: 149. 1883; Cooke, Fl. Pres. Bombay 2: 275. 1958 (Repr.); Kazmi in J. 
Arnold Arbor. 51: 179. 1970. Naik, Fl. Osmanabad. 213. 1979; Ugemuge, Fl. Nag. Dist. 243. 1986.

Procumbent herb; stem silky pubescence. Leaves elliptic, ovate, obovate, base rounded, truncate, apex obtuse or subacute, white silky pubescence on both side. Flowers in usually terminal 2- ranked, simple or forked scorpioid cymes. Sepals almost fused, white silky. Corolla tubular, lobes spreading, elliptic oblong, acute or obtuse, white. Stamens and style included. Fruit ovate, containing 2- nutlets. Seeds angled, rough, glabrous and hairy at angles, cream coloured.

Occasional in fields as weed. Fls. \& Frs. Oct.May. Navtala, 368.

\section{Heliotropium sp. ?}

Erect herb up to $30-40 \mathrm{~cm}$ high; stem sparsely bulbous based hairy. Leaves all petiolate, alternate, opposite and sub-opposite, ovate, lanceolate, $4.5-6.0 \times 2.0-3.0 \mathrm{~cm}$, base truncate or cuneate, sub- serrate margins, apex acute, acuminate, more or less glabrous except few scattered white bulbous based hairs on midrib and lateral veins, hairs more beneath than above; petioles $2.0-3.0 \mathrm{~cm}$ long, scattered hairy. Flowers in usually terminal 2- ranked, simple or forked scorpioid cymes. Sepals equal, ovate lanceolate, acute, hairy outside. Corolla tubular, bluish- white with yellowish orange throat, lobes spreading, almost fused, obtuse. Stamens and styles included. Fruits dry, oval, glabrous; nutlets connate by pairs, sometimes more or less separable into 4- nutlets. Nutlets 2- 4, angled, beaked, brown.

Rare in grass land in water lodged soil. Fls. \& Frs. Aug.- Dec. Saori, 452.

Note: I have seen only two plants in the region. I could not find any sp. showing exact similar characteristics in available literature with me. While this sp. show some what similarity with $H$. tuberculosum, Boiss., but distinct by leaf characters.

\section{ROTULA Lour.}

Rotula aquatica Lour. Fl. Cochinch. 121. 1790; Gamble, Fl. Pres. Madras 2: 627. 1957 (Repr.). Rhabdia lycicoides Mart. Nov. Gen. \& Sp. 2: 137 , t. 195. 1826; C. B. Cl. in Hook. f. F. Brit. India 4: 145. 1883; Cooke, Fl. Pres. Bombay 2: 272. 1958 (Repr.).

A small much branched sturdy shrub; branches virgate, with numerous arrested branchlets, glabrous or nearly so. Leaves shortly subsessile, crowed, elliptic- oblanceolate, base rounded or cuneate, entire, obtuse, glabrous. Sepals slightly unequal, all ovate- lanceolate, more or less hairy. Corolla tubular, whitishpink or white, limbs spreading, oblong, obtuse. Stamens slightly exserted. Fruit orange, ovoid. Seeds oblong.

Common in river banks. Fls. \& Frs. Nov.- Apr. Dharmapuri / Kumbhali, 262.

\section{TRICHODESMA R. Br. (nom. Cons.)}

1. Stamens included. $\quad . . \quad$ T. inaequale

\section{Stamens exserted:}

2. Leaves linear lanceolate, auricled at the base. ... T. indicum

2. Leaves obovate to elliptic- oblong, cuneate at the base. $\quad$... T. zeylanicum

Trichodesma inaequale Edgew. in Asiat. Soc. Bengal 21: 175. 1853; Verde, in Kew Bull. 44: 700. 1989. T. amplexicaue sensu A. DC. in DC. Prodr. 10: 172. 1846 p.p.; C.B.C1. in Hook. f. Fl. Brit. India 4: 153. 1883 p.p. T. indicum var. amplexicaule T. Cooke, Fl. Pres. Bombay 2: 215. 1904 [2: 282. 1958 (Repr.)] p.p.; $T$. sedgwickianum Banerjee in Bull. Bot. Soc. Bengal 16: 10. (1962) 1964. 'GHANWAL'

Erect branched herb; stem and branches scabrid- hispid. Leaves basal opposite, upper alternate, oblong- lanceolate, base amplexicaule, margin bristly, hispid on upper side along midrib and primary laterals, while all over beneath. All hairs develops from the bulbous base. Flowers in leaf oppose solitary or terminal cymes. Sepals ovate, sagittate, hastate, acute, scabrid. Corolla tubular, white, lobes mucronate. Stamens and styles included. Fruits pyramidal, ribbed. Nutlets 4, glabrous.

Common in grass land on waste land, agricultural field bunds. Fls. \& Frs. Aug.- Dec. Somalwada Rd. Kinhi, 02.

T. indicum (L.) Lehm. PI. Fam. Asperif. 193. 1818; C.B.C1, in Hook. f. Fl. Brit. India. 4: 153. 1883; Cooke, Fl. Pres. Bombay 2: 281. 1958 (Repr.); Kazmi in J. Arnold Arbor. 52: 516. 1971; Borago indica L. Sp. PI. 137. 1753. Trichodesma amplexicaule Roth, Nov. Sp. PI. 104. 1821; C.B.C1 in Hook. f. op. cit. p. p. T. indicum var. amplexicaule (Roth) T. Cooke, Fl. Pres. Bombay 2: 215. 1904 [2: 282. 1958 (Repr.)]. 'CHHOT KALPA'.

Procumbent herb; stem and branches hispid hairy. Leaves linear or oblong lanceolate, base auricled, apex acute, hispid hairy above, villous 
beneath. Flowers extra- axillary solitary or terminal cymes. Sepals hastate, acute, silky hairy. Corolla tubular campanulate, lobes, obovate, spirally twisted acuminated, sky blue or white, purple tinged. Staminal column exserted. Fruit dry containg 2-4 nutlets. Seeds oval, angled, glabrous and shining on convex.

Occasional in waste land. Fls. \& Frs. Oct.- May. Rawanwadi lake side, 386.

T. zeylanicum (Burm. f. ) R. Br. Prodr. 496. 1810; C.B.C1. in Hook. f. Fl. Brit. India 4: 154. 1883; Cooke, Fl. Pres. Bombay 2: 282. 1958 (Repr.); Banerjee \& Pramanik in Bull. Bot. Surv. India 17: 120. (1975) 1978. Borago zeylanica Burm. f. Fl. Ind. 41, t. 14, f. 2. 1768. 'JAL SHIRSI'.

Erect hispid herb; stem and branches clothed with hispid hairs. Leaves oblanceolate, oblong, acute or sub-obtuse, dense hairy above, few hairs beneath. Flowers in uaually terminal cymes. Sepals lanceolate, rounded at the base, acute, hairy. Corolla tubular campanulate, lobes, obovate, spirally twisted acuminated, sky blue, purple tinged. Staminal column exserted. Fruit with 4-nutlets, enclosed in persistent calyx. Nutlets sub-obtuse, rough.

Occasional in sandy soils, in grass land, waste land and agricultural fields. Fls. \& Frs. Sept.Jun. Gose, 433.

\section{CONCLUSION :}

In Maharashtra the family is represented by 10 genera, 32 species, 04 subspecies and 03 varieties. In Bhandara district seven taxa are already reported, out of which Cordia dichotoma Forst., E. laevis Roxb., and Rotula aquatica Lour. are initially reported by Haines, H. H. 1916. in Discriptive List of Trees, Shrubs and Economic Herbs of the Southern Circle, Central Provinces, while Coldenia procumbens L., Rotula aquatica Lour., T. indicum (L.) Lehm., Trichodesma inaequale Edgew., T. zeylanicum (Burm. f. ) R. Br., are reported by S. K. Malhotra and K. Madhusudhan Rao in J. Econ. Tax. Bot. 2:1981. During floristic investigation 11 taxa have been reported, out of which $H$. indicum L., $H$. ovalifolium Forssk. Fl., $H$. supinum L.,
Heliotropium sp. ?, are new records for the region.

\section{REFERANCES :}

Acharya, R. H. (1984). Flora of Almeida, M. R. (1996-2003). Flora of Maharashtra, Vol. 14. Blatter Herbarium, St. Xavier's College, Mumbai.

Wardha District, Ph.D. Thesis (Unpublished), Nagpur University, Nagpur.

Chaturvedi Alka. (1984). Flora of Ratlam District (M. P.), Ph. D. Thesis (Unpublished), Devi Ahilya University, Indore.

Cherian, P. J. and Pataskar, R. D. (1969). Contribution to the flora of Saptashringi and adjoining hills, Maharashtra. Bull. Bot. Surv. India. 11: 23-24, Map. 1, Tab. 1.

Cooke, T. (1958). The Flora of the Presidency of Bombay. Vol. I-III, (BSI reprint), Calcutta.

Deshpande, B. D. and Bhatnagar, P. (1961). Flora of Chandmari Hillocks, Wardha (Maharashtra). J. Ind. Bot. Soc. 42: 143154.

Dhore, M. A. (1986). Flora of Amravati District with special reference to the distribution of Tree species, Ph.D. Thesis (Unpublished), Nagpur University, Nagpur.

Haines, H. H. (1916). Descriptive list of Trees, shrubs and Economic herbs of Southern Circle, Central Provinces, Allahabad.

Hippalgaonkar, K. V. (1972). Some new records of plants in the flora of Aurangabad, Biol. J. Sci. 15: 47.

Jain, S. K. (1986). The Grass flora of India- A synoptic account of uses and phytogeography. Bull. Bot. Surv. India. 10 (384): 280-282. 
Kamble, S. Y. and Pradhan, S. G. (1988). Flora of Akola District, Maharashtra. Botanical Survey of India, Pune.

Karthikeyan, S. and Anand Kumar (1993). Flora of Yavatmal District, Maharashtra, Botanical Survey of India, Kolkata.

Kothari, M. J. and Moorthy, S. (1993). Flora of Raigad District in Maharashtra State, Botanical Survey of India, Kolkata.

Malhotra, S. K. and Madhusudan Rao, K. (1981c). A contribution to the flora of Bhandara district, Maharashtra state (India). J. Econ. Tax. Bot. 2: 107-136.

Naik, V. N. (1998). Flora of Marathwada. Amrut Prakashan, Aurangabad.

Saldana, C. J. and Nicolson, D. H. (1976), Flora of Hassan District, Karnataka, India, New Delhi.

Sharma, B. D., Karthikeyan, S. \& Singh, N. P. (Edited by) (1996). Flora of Maharashtra State (Monocotyledones), (BSI print), Calcutta.

Singh, N. P. \& Karthikeyan (eds.) (2000). Flora of Maharashtra State (Dicotyledones), Vol-I, (BSI print), Calcutta.

Ugemuge, N. R. (1986). Flora of Nagpur District. Shree Prakashan, Nagpur. 